\title{
DYNAMIC SIMULATION OF A CRUDE OIL DISTILLATION PLANT USING ASPEN-HYSYS ${ }^{\circledR}$
}

\author{
Sotelo, D. ; Favela-Contreras, A., ${ }^{*}$; Lozoya, C. ${ }^{*}$; Beltran-Carbajal, F. ${ }^{* *}$; Dieck-Assad, G. ${ }^{*} \&$ \\ Sotelo, C." \\ *Tecnologico de Monterrey, Escuela de Ingenieria y Ciencias, Mexico \\ ** Universidad Autónoma Metropolitana, Unidad Azcapotzalco, Departamento de Energía, Mexico \\ E-Mail: ing_davidsotelo@hotmail.com, antonio.favela@itesm.mx, camilo.lozoya@itesm.mx, \\ fbeltran@azc.uam.mx, graciano.dieck.assad@itesm.mx,ing_carlossotelo@hotmail.com \\ ( ${ }^{\#}$ Corresponding author)
}

\begin{abstract}
Petroleum subproducts are obtained in a crude oil distillation plant. Here, due to the chemical properties of the crude oil, a series of complex reactions occurs, and measurements are not always feasible. This poses a challenge to analyse the outcome of the process under real operating conditions. To overcome these difficulties, this paper presents an unpublished modelling and dynamic simulation of a complete distillation plant using Aspen $\operatorname{HYSYS}^{\circledR}$ environment. The process involves four major stages: preflash, atmospheric, stabilizer and vacuum, in which condensers, reboilers, heat exchangers, distillation columns and side strippers are designed based on a deep literature review. Moreover, considering that actual refinery plants work with fixed yields set by plant operators, the present work proposes a control strategy that continuously estimates and obtains stable distillate flows of kerosene, diesel and atmospheric gas oil. The simulation results show the comparison of the modelling parameters with actual data and the performance of the crude oil distillation plant under the implemented control system.

(Received in September 2018, accepted in March 2019. This paper was with the authors 2 months for 1 revision.)
\end{abstract}

Key Words: Crude Oil Distillation Plant, Modelling, Simulation, Aspen HYSYS ${ }^{\circledR}$

\section{INTRODUCTION}

A crude oil distillation plant involves many integrated complex processes, this possess a big challenge to conduct an analysis of its operation. For this reason, simulation has become an important tool in the behaviour study of this kind of petrochemical plants [1]. However, due to their strong interactions and complex dynamics, modelling and simulation of distillation processes turns into a difficult task [2]. As it is well-mentioned in [3, 4], steady state modelling and simulation in chemical process simulators environment is fairly standard today, and only little is known about the dynamic simulation in the open literature. Some steady state simulations of distillation units are encountered in the research field [5-7]. In [5], optimization of crude distillation unit of Kaduna Refinery and Petrochemical Company was carried out using Aspen HYSYS ${ }^{\circledR}$ simulator. Moreover, considering three different crudes, one each from Persian Gulf, Indian origin and Arabian origin, in [6] a model is developed using measured plant parameters to predict various product properties. In [7], considering two different crudes, Dubai-Basara and Dubai-Bomby, preflash, atmospheric, and vacuum distillation units are performed using an Aspen Plus simulator. Nevertheless, as it is mentioned in [1], since petrochemical plants do not operate in steady state, these models are of limited usefulness in studying routing operation. On the other hand, [1, 8-11] present a dynamic simulation. In [1, 10], Aspen HYSYS ${ }^{\circledR}$ is used for the analysis of the operation of an atmospheric distillation unit of a crude oil refinery under a control structure. Furthermore, preflash and atmospheric columns of a real crude oil distillation plant are performed using ASPEN simulations in [8]. In [9] atmospheric and vacuum distillation units are modelled using DIVA software environment. Moreover, in [11] crude oil atmospheric distillation unit is performed using 
Aspen Plus, and simulations results are compared with experimental data. However, these dynamic models simulate only some crude oil units which do not represent a realistic distillation plant. For this reason, considering the lack of proper simulation, the present work is aimed to develop a rigor and an accurate modelling simulation of a complete distillation crude oil plant using Aspen HYSYS ${ }^{\circledR}$ environment in dynamic mode. Hence, design and sizing equipment and pressure temperature profiles for each stage of the process are described in detail. Additionally, unlike previous research works [12-15] where advanced control strategies are implemented, in the present work a PID-based control strategy is proposed to regulate the flow rate extractions and preserve the entire plant stability. This, to be handily implemented in real distillation plants, which nowadays work with fixed flow distillates affecting the product quality [16].

This paper is structured as follows: Section 2 presents a brief description of the process. Section 3 describes in detail how the process is modelled and simulated in dynamic mode using Aspen HYSYS ${ }^{\circledR}$. In Section 4, the simulation results show the comparison of the modelling parameters with actual data, and the performance of the crude oil distillation plant under the implemented control system is presented. Finally, in Section 5, the conclusions of this work and suggestions for further research are mentioned.

\section{DISTILLATION PROCESS}

Crude oil is a complex mixture of hydrocarbons that must be processed to make it usable. The process commonly used takes place in a distillation plant (Fig. 1). Here, the input crude oil is feed to the preflash stage to evaporate its light components. Then, heating-up the crude oil by a furnace, in the atmospheric stage, distillate products such as naphtha, kerosene, diesel, atmospheric gas oil (AGO) and atmospheric residue are obtained depending on its boiled-off temperature. Temperature and pressure profiles are maintained by strippers and pumparounds. In the stabilizer stage, the naphtha is treated at higher pressure and its light ends are removed, thus, combustible gas, liquefied petroleum gas (LPG) and naphtha stabilized are obtained. Finally, in the vacuum stage the residue is conducted at lower pressure to obtain petroleum products: top, bottom, light liquid and heavy liquid gas oil (LVGO and HVGO).

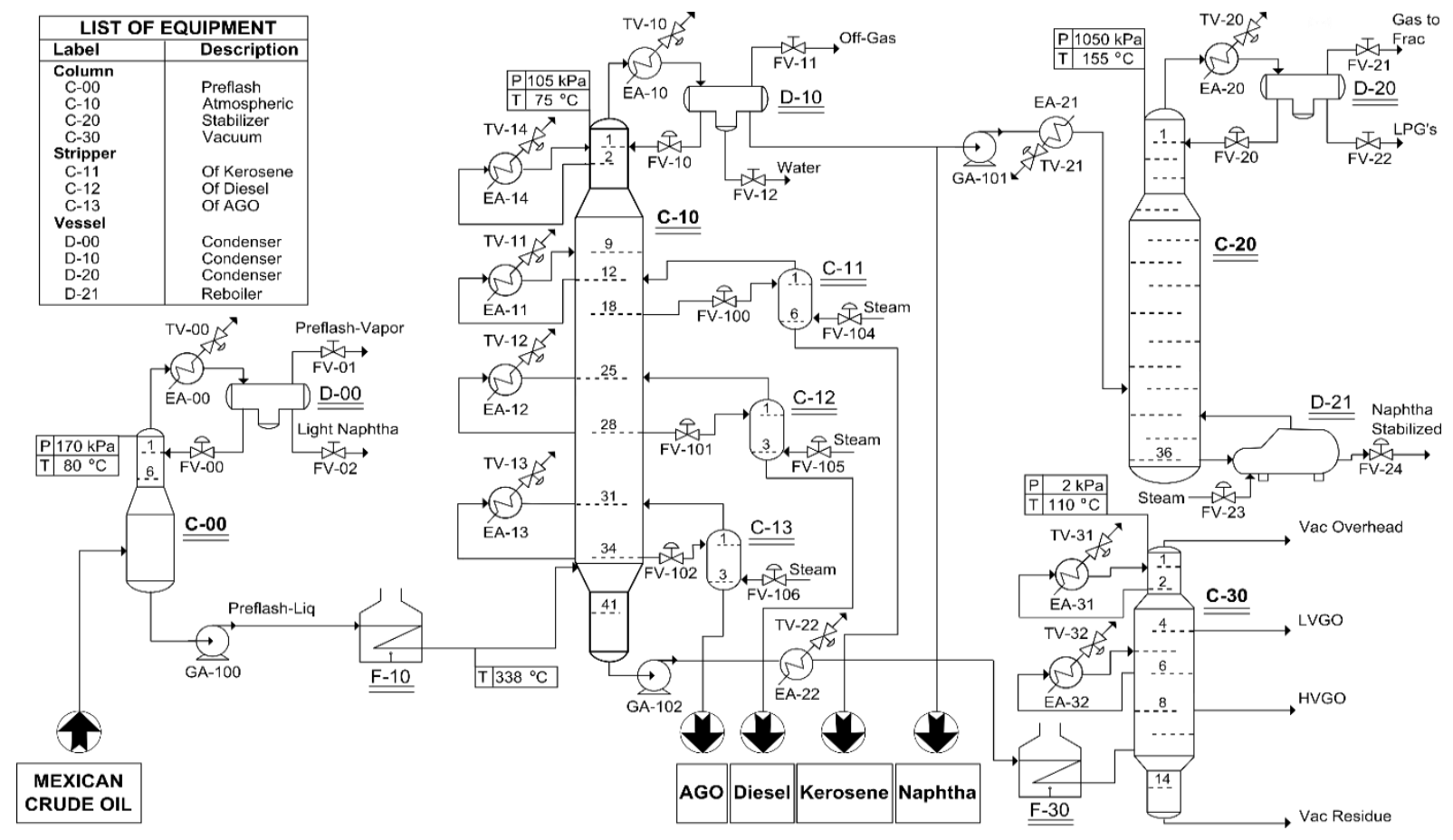

Figure 1: Process flowsheet. 


\section{MODELLING AND SIMULATION}

The distillation plant is built-up using Aspen HYSYS ${ }^{\circledR}$. As in [17-19], the units are rigorously designed according to its operating conditions and theoretical data reported in the literature field. Hence, as in [10, 20], Peng-Robinson fluid package is used as a robust database for Vapour-Liquid Equilibrium calculations and Vapour-Liquid Phases property predictions.

\subsection{Steady state modelling}

To provide the input feed for the distillation plant, three Mexican crude oils (Olmec, Isthmus and Maya) are inlet into a Mixer. The petroleum properties such as sulphur content, viscosity, density, boiling point and API (American Petroleum Institute) gravity, which ranges from 10 to $33^{\circ}$, are set for each input stream. Thus, Table I shows the IBP (Initial Boiling Point) and FBP (Final Boiling Point) for the side extractions in the atmospheric distillation column.

Table I: Crude oil range temperatures.

\begin{tabular}{|c|c|c|}
\hline Fraction & IBP $\left({ }^{\circ} \mathrm{C}\right)$ & FBP $\left({ }^{\circ} \mathrm{C}\right)$ \\
\hline Naphtha & 70 & 180 \\
\hline Kerosene & 180 & 240 \\
\hline Diesel & 240 & 340 \\
\hline AGO & 340 & 370 \\
\hline Residue & 370 & 932 \\
\hline
\end{tabular}

The preflash column $(\mathrm{C}-00)$ is modelled by 6 trays, and it operates at a pressure of 170 $\mathrm{kPa}$ and temperature of $42.7^{\circ} \mathrm{C}$. Here, the feed stream is split into its vapor pashes (PreFlashVap) and liquid phases (Light Naphtha and PreFlash-Liq). Its condensing section is represented by a partial condenser (D-00) where a single exchanger (Q-00) is implemented to reduce its temperature.

The atmospheric distillation column (C-10) corresponds to the most important unit in the refining process. It is modelled by 29 trays, and it operates at a pressure of $104 \mathrm{kPa}$ and temperature of $76.9^{\circ} \mathrm{C}$. It has three physical components called strippers (see Table II) to draw out: kerosene, diesel and atmospheric gas-oil (AGO). Naphtha is drawn from a partial condenser (D-10) and atmospheric residue (Residue) from the bottom of the column. Before the refined light oil enters to the main column, a furnance (F-10) is simulated to heat it from $228.4^{\circ} \mathrm{C}$ up to $338.4^{\circ} \mathrm{C}$ by $\mathrm{W}-10$. In this case, to draw off heat from column stages, four pump arounds are located along the column. A fraction of distillate product is taken out from the unit. This hot liquid stream is directed aside to be sub cooled and returned trays above. The pumparounds are simulated as heat exchangers with a fixed duty (see Table III).

Table II: Strippers of the atmospheric distillation column.

\begin{tabular}{|c|c|c|c|c|c|}
\hline Stripper & Product & No. of stages & Draw stage & Return stage & Flow rate (barrels/day) \\
\hline C-11 & Kerosene & 6 & 13 & 12 & 14000 \\
\hline C-12 & Diesel & 3 & 17 & 16 & 20000 \\
\hline C-13 & AGO & 3 & 22 & 21 & 5000 \\
\hline
\end{tabular}

Table III: Pumparounds of the atmospheric distillation column.

\begin{tabular}{|c|c|c|c|c|}
\hline Pumparound & Draw stage & Return stage & Flow rate (barrels/day) & Duty (MMBTU/h) \\
\hline EA-11 & 12 & 9 & 20000 & -30 \\
\hline EA-12 & 17 & 16 & 30000 & -35 \\
\hline EA-13 & 22 & 21 & 30000 & -35 \\
\hline EA-14 & 2 & 1 & 50000 & -20 \\
\hline
\end{tabular}


The stabilizing column (C-20) is modelled to remove light components from the heavy stream. The feed tray (15 500 barrels/day, approximately) enters at the middle of the column, which is designed to operate at a pressure of $1030 \mathrm{kPa}$ and temperature of $159.1^{\circ} \mathrm{C}$. At the beginning, a pump (GA-101) is used to pressurize the naphtha up to $1825 \mathrm{kPa}$ and a preheat section (EA-21) to heat it up to $250^{\circ} \mathrm{C}$. The feed comes down to the bottom trays and light material vaporizes. Thus, at the top of the column, the temperature of the total condenser (D-20) is reduced by a heat exchanger Q-20, and LPG product is obtained. Moreover, at the bottom of the column, purified heavy material (Naphtha Stabilized) is obtained by a reboiler (D-21) designed as a Kettle reboiler (Once-through).

Finally, to evaporate the heaviest components of the refining process and to recover additional distillates from atmospheric residue, the vacuum column (C-30) is modelled. It is designed to operate at a pressure of $2 \mathrm{kPa}$ and at a temperature of $112^{\circ} \mathrm{C}$. At this stage, 40000 barrels/day of Residue are feed using a pump (GA-102), and its temperature is kept at $408.5^{\circ} \mathrm{C}$ by a heater (F-30). Moreover, four extractions are performed, and pumparounds (see Table IV) are modelled as heat exchangers to decrease the vapour load along the unit.

Table IV: Pumparounds of the vacuum distillation column.

\begin{tabular}{|c|c|c|c|c|}
\hline Pumparound & Draw stage & Return stage & Flow rate (barrels/day) & Duty (MMBTU/h) \\
\hline EA-31 & 2 & 1 & 22400 & -13 \\
\hline EA-32 & 6 & 5 & 50000 & -85 \\
\hline
\end{tabular}

\subsection{Dynamic modelling}

Before steady-state simulation is exported, dynamic requirements for columns and strippers are set according to the input crude oil composition of 99000 barrels/day. As in $[10,11]$, the tray sizing tool available in Aspen HYSYS $^{\circledR}$ is used to calculate the required data. The columns and side strippers are separated into sections, and their sizing parameters, such as section diameter, weir height, tray spacing, total weir length, and maximum pressure drop Max $\Delta P$ per tray (Fig. 2), are chosen from the tray with the largest diameter. After the number of internal flow paths is proposed [21], the weir length is calculated by Eq. (1). Finally, bottom pressure is obtained adding the maximum pressure drop to the top pressure Eq. (2):

$$
\begin{gathered}
\text { Weir length }=\frac{\text { Total weir length }}{\text { No. of internal flow paths }} \\
\text { Bottom pressure }=\text { Top pressure }+(\text { Max } \Delta P / \text { Tray }) \text { (No. of trays })
\end{gathered}
$$

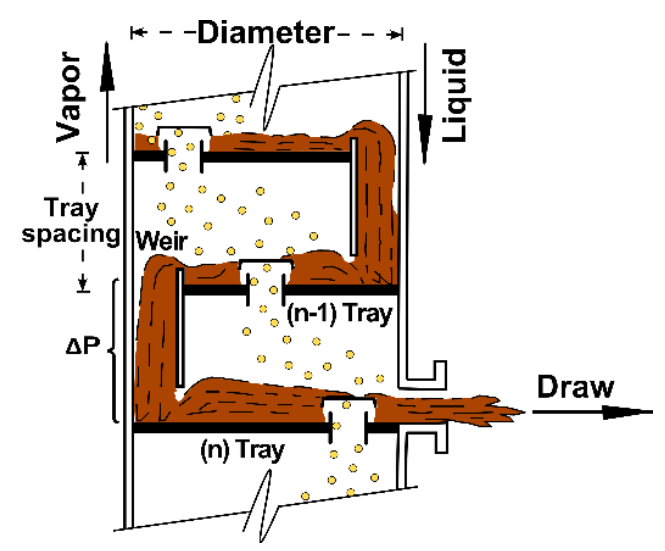

Figure 2: Column parameters.

The tray spacing in distillation units are closely related with the column diameter and the operating conditions. To ensure that entrained gasses can be separated from the liquids in the downcomers, typically the tray spacing for columns with diameters above $1 \mathrm{~m}$ varies from 0.3 
to $0.61 \mathrm{~m}$. In this case, as in [22, 23], a default tray spacing of $0.6096 \mathrm{~m}$ and a standard size of weir height of $0.0508 \mathrm{~m}$ for distillation columns and side strippers are set. The remaining tray section parameters, top pressures and bottom pressures are specified in Table V.

Table V: Geometric parameters for the columns and strippers.

\begin{tabular}{|c|c|c|c|c|}
\hline Column/Stripper & $\begin{array}{c}\text { Diameter } \\
(\mathrm{m})\end{array}$ & $\begin{array}{c}\text { Weir length } \\
(\mathrm{m})\end{array}$ & $\begin{array}{c}\text { Top pressure } \\
(\mathrm{kPa})\end{array}$ & $\begin{array}{c}\text { Bottom pressure } \\
(\mathrm{kPa})\end{array}$ \\
\hline $\mathrm{C}-00$ & 3.20 & 2.56 & 170 & 415.79 \\
\hline $\mathrm{C}-10$ & 6.25 & 4.92 & 104 & 198.54 \\
\hline $\mathrm{C}-11$ & 1.83 & 1.53 & 144.5 & 185.95 \\
\hline $\mathrm{C}-12$ & 1.98 & 1.60 & 158 & 187.02 \\
\hline $\mathrm{C}-13$ & 1.22 & 0.96 & 174.9 & 193.46 \\
\hline $\mathrm{C}-20$ & 2.59 & 2.09 & 1030 & 1043.752 \\
\hline $\mathrm{C}-30$ & 5.49 & 4.35 & 2 & 14.47 \\
\hline
\end{tabular}

Additionally, due to condensers and reboilers (Fig. 3) require proper sizing to operate in Aspen HYSYS ${ }^{\circledR}$ dynamic mode [21], the vessel volume is defined by the total liquid out flow $\dot{Q}_{\text {out }}$, the residence time $R T$, and the liquid level residence volume $L L R V$, Eq. (3):

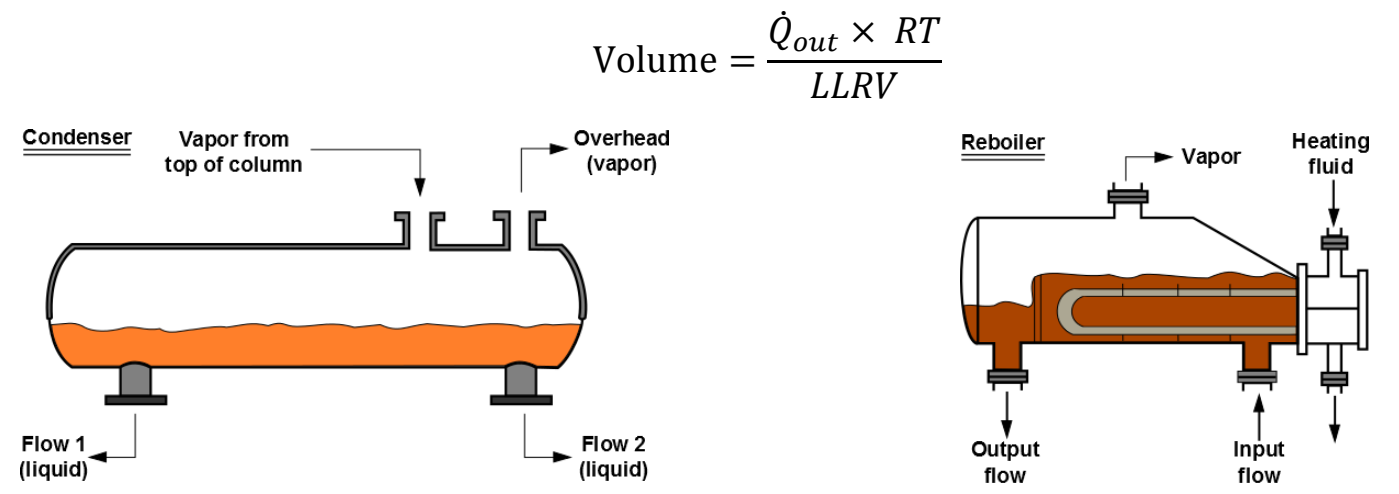

Figure 3: Vessels.

Here, the vessel operations are designed to have a cylindrical geometry. The condensers have a vertical orientation, considering that there are significant quantities of noncondensible components, while the reboiler has a horizontal orientation, to guarantee that pure components are obtained. The parameters for these vessel operations are described in Table VI.

Table VI: Design parameters for vessels.

\begin{tabular}{|c|c|c|c|c|}
\hline Vessel & Total outflow $\left(\mathrm{m}^{3} / \mathrm{h}\right)$ & Volume $\left(\mathrm{m}^{3}\right)$ & Diameter $(\mathrm{m})$ & Heir/Length $(\mathrm{m})$ \\
\hline D-00 & 73.16 & 24.39 & 2.746 & 4.119 \\
\hline D-10 & 278.476 & 92.82 & 4.287 & 6.431 \\
\hline D-20 & 91.08 & 30.36 & 2.954 & 4.431 \\
\hline D-21 & 96.06 & 32.02 & 3.007 & 4.510 \\
\hline
\end{tabular}

During distillation the vapour flows upwards, and leaves the column at the top. Then, the vapours are cooled and condensed in the vessel. In order to achieve stability along the columns, its operating temperature and pressure must be regulated. In this case (Fig. 4), the temperature is regulated regards to the liquid level PID controller LIC-10 in the condenser. Thus, the condensed stream that goes to reflux drum is manipulated and flow disturbances into the units are smoothed. Similarly, the operating condenser pressure is controlled by a PID controller PIC-10 which removes the excess of heat [24]. On the other hand, to avoid thermal cracking in the input of the atmospheric stage, a PID controller TIC-10 keeps the atm. Crude 
temperature at $338.4{ }^{\circ} \mathrm{C}$. Additionally, FIC-14 maintains the distillate flow of Naphtha regulating the pump input power in GA-101.
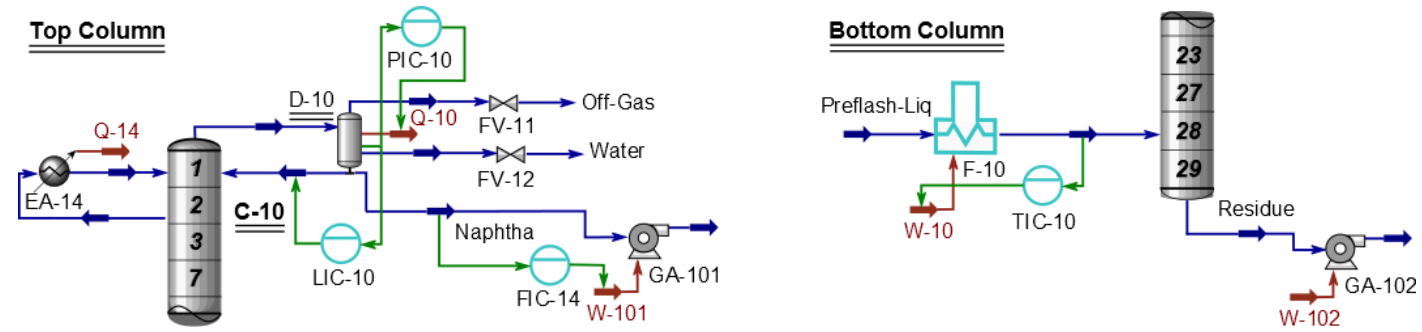

Figure 4: Atmospheric distillation column under commonly top control structure.

Moreover, to define the control structure that maintains the subproduct flowrates of Kerosene, Diesel and AGO, two different single feedback configurations and a proposed cascade control loop are considered (Fig. 5). For the $1^{\text {st }}$ Single Feedback control strategy, the output distillate flow is regulated based on the liquid level in the last tray of the stripper. For the $2^{\text {nd }}$ Single Feedback control strategy, the product flow is regulated measuring the liquid volumetric flow of the distillate. Finally, for the Cascade control strategy, the output distillate flow is measured and a PID controller generates the reference for the liquid level control system of the stripper, this control scheme is useful to reject disturbances [25].
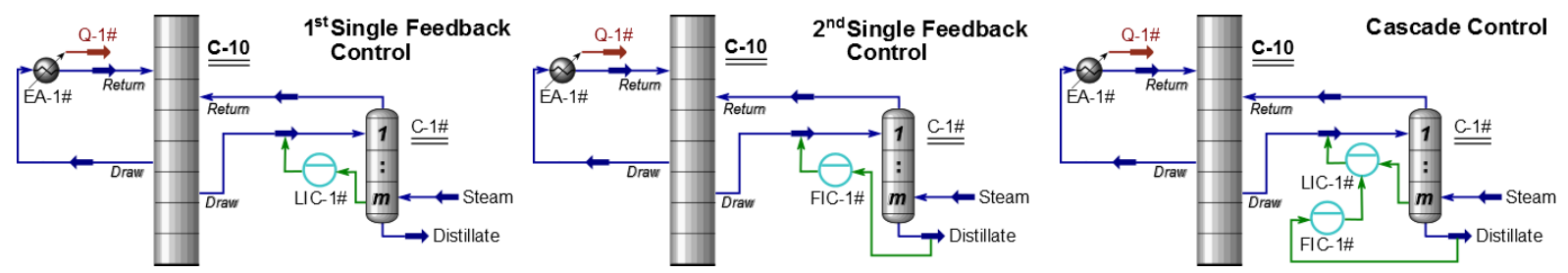

Figure 5: Control structures to determine the crude oil subproduct flowrates.

Based on the proposed control structures (Fig. 5), Fig. 6 shows the performance of the implemented control configurations when the demand of distilled flows is increased. The $2^{\text {nd }}$ Single Feedback control strategy has better performance regulating the subproduct flowrates of Kerosene and AGO, while the cascade control loop regulates faster the distilled flow of Diesel. However, to obtain a soft response and preserve stability in the column, the $2^{\text {nd }}$ Single Feedback control strategy is also chosen.

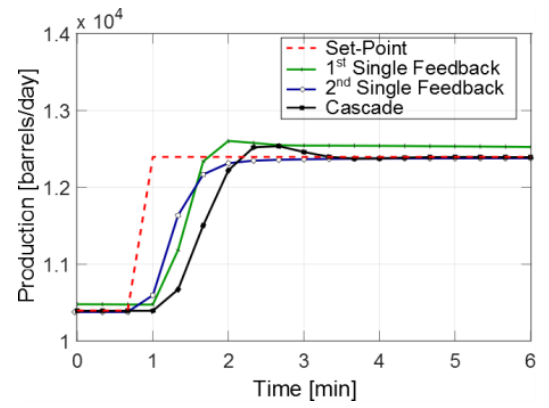

a)

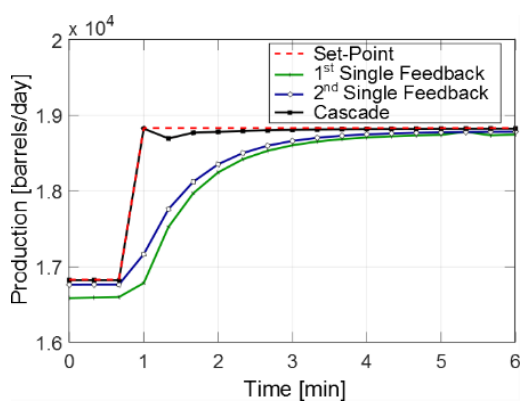

b)

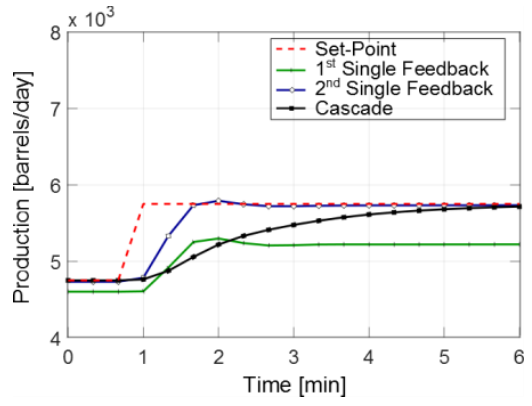

c)

Figure 6: Distillate flow of: a) Kerosene, b) Diesel and c) AGO under different control strategies.

In a typical crude oil refinery plant, the controllers that regulate the side extractions works with fixed setpoints [16], which turns into an ineffectual performance when dealing with input disturbances. To avoid this, most of the times the quantity of distillates products relies heavily on the expertise of refinery plant operators. This implies a poor stability performance in the system and results in crude distillates outside its corresponding range of temperatures. In the 
present work, the desired volumetric flow of each product yield is continuously estimated. First of all, as shown in Fig. 7, the fractions are computed in stationary mode, Eq. 4:

$$
\text { Fraction }_{i}=\frac{\dot{Q}_{i-\text { initial state }}}{\sum_{j=0}^{n} \dot{Q}_{j-\text { initial state }}}
$$

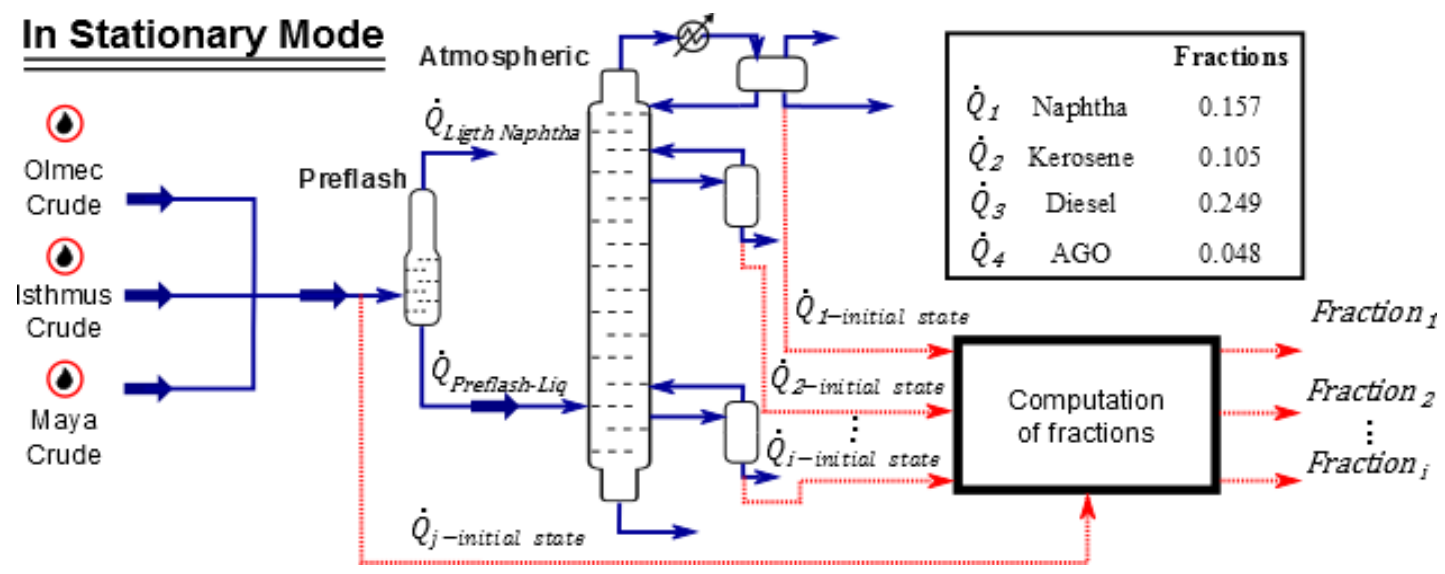

Figure 7: Computation of distillates fractions.

Then, considering that crude oil units have a significant amount of stripping steam as their feeds [26], the overall feed flow $\dot{Q}_{j}$ is approximately the liquid volumetric at the bottom of the Preflash $\dot{Q}_{\text {Preflash-Liq. }}$. This corresponds to the input crude oil of atmospheric column, Eq. (5):

$$
\dot{Q}_{\text {Preflash-Liq }}=\sum_{i=0}^{n} \dot{Q}_{i}
$$

where $\dot{Q}_{i}$ corresponds to the volumetric flow in the corresponding side extraction $i$ (Naphtha, kerosene, Diesel, AGO, and Residue). Hence, in dynamic mode, each side extraction could be estimated using the overall feed flow and its corresponding distillate fraction (Fig. 8). Thus, by Eq. (6) the remote setpoints $S P_{i}$ for the controllers (FIC-1, FIC-2, ..., FIC- $i$ ) of the side extractions in the atmospheric column are defined.

$$
S P_{i}=\sum_{j=0}^{n} \dot{Q}_{j} * \text { Fraction }_{i}
$$

\section{In Dynamic Mode}

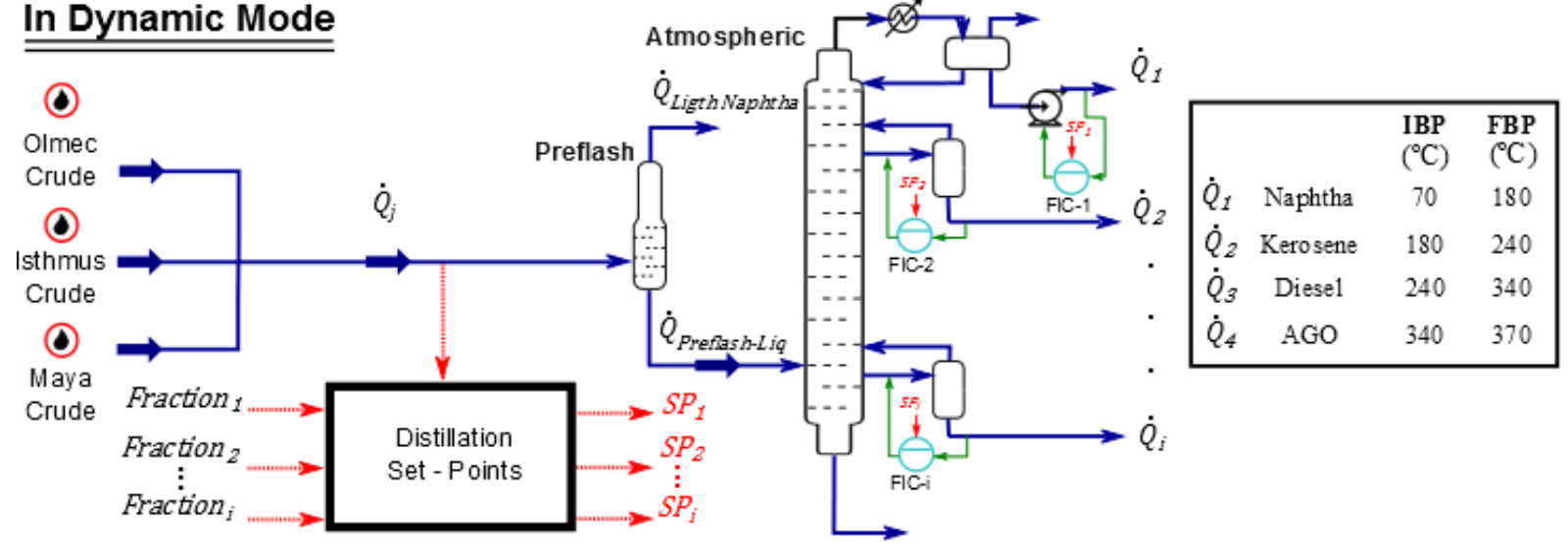

Figure 8: Computation of remote Set-Points for distillates products.

The control structure for the simulated distillation plant is presented in Fig. 9. As in [27, 28], authors decided to use PID controllers instead of more advanced controllers. This was motivated to be handily implemented in real distillation plants. 


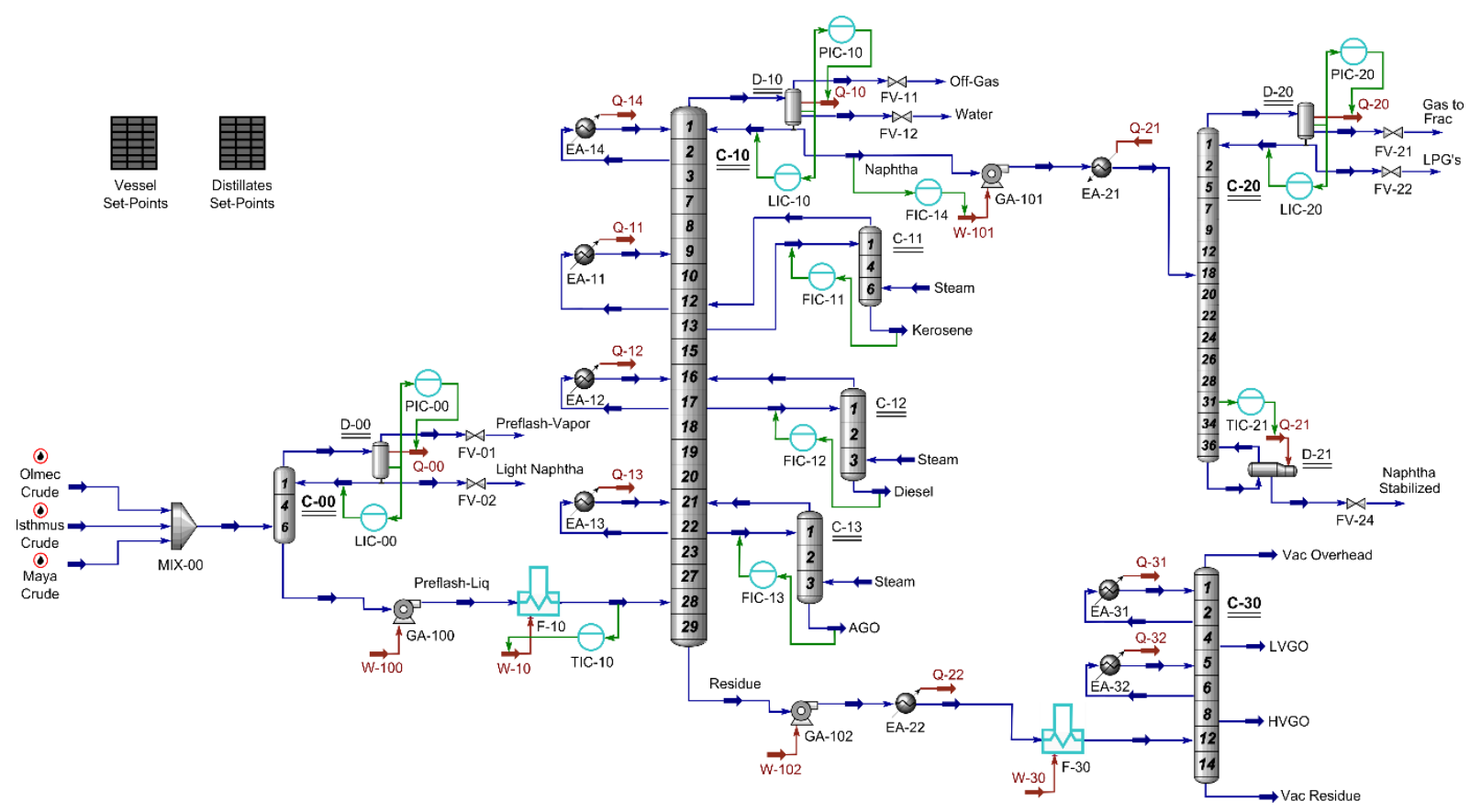

Figure 9: Control process flowsheet.

\section{SIMULATION RESULTS}

In this section, diameter, weir length and top pressure of columns are compared with theoretical values. Additionally, temperature and pressure profiles are presented. Finally, the behaviour of the plant in dynamic regime is evaluated after changing the crude oil feed flowrate.

\subsection{Modelling results}

Table VII shows that column diameters are closed to theoretical typical values [29-34], and the weir length of columns and strippers are between 60-85\% of their diameter section [35]. Moreover, Table VIII shows that top pressures are not far from those specified in Fig. 1.

Table VII: Dynamic requirements comparison.

\begin{tabular}{|c|c|c|c|c|}
\hline \multirow{2}{*}{ Column/Stripper } & \multicolumn{2}{|c|}{ Diameter $(\mathrm{m})$} & \multicolumn{2}{c|}{ Weir length $(\mathrm{m})$} \\
\cline { 2 - 5 } & Simulation & Typical & Simulation & Typical \\
\hline C-00 & 3.20 & 3.39 & 2.56 & $2.03-2.88$ \\
\hline C-10 & 6.25 & 6.10 & 4.92 & $3.66-5.19$ \\
\hline C-11 & 1.83 & 1.83 & 1.53 & $1.10-1.60$ \\
\hline C-12 & 1.98 & 1.83 & 1.69 & $1.10-1.60$ \\
\hline C-13 & 1.22 & 1.52 & 0.96 & $0.91-1.29$ \\
\hline C-20 & 2.59 & 2.75 & 2.09 & $1.65-2.34$ \\
\hline C-30 & 5.49 & 5.19 & 4.35 & $3.11-4.41$ \\
\hline
\end{tabular}

Table VIII: Operating top pressures comparison.

\begin{tabular}{|c|c|c|}
\hline \multirow{2}{*}{ Column } & \multicolumn{2}{|c|}{ Top pressure $(\mathrm{kPa})$} \\
\cline { 2 - 3 } & Simulation & Typical \\
\hline C-00 & 170 & 170 \\
\hline C-10 & 104 & 105 \\
\hline C-20 & 1030 & 1050 \\
\hline C-30 & 2 & 2 \\
\hline
\end{tabular}


Temperature and pressure profiles of distillation columns are shown in Fig. 10 and Fig. 11, respectively. Fig. 10 shows how temperatures in output products of the columns vary according to their extraction point; the lower the extraction point, the higher the temperature value. Similarly, Fig. 11 shows that the pressure increases along the columns, while the bottom and the top pressures correspond to the values specified in Table V and Table VII respectively.

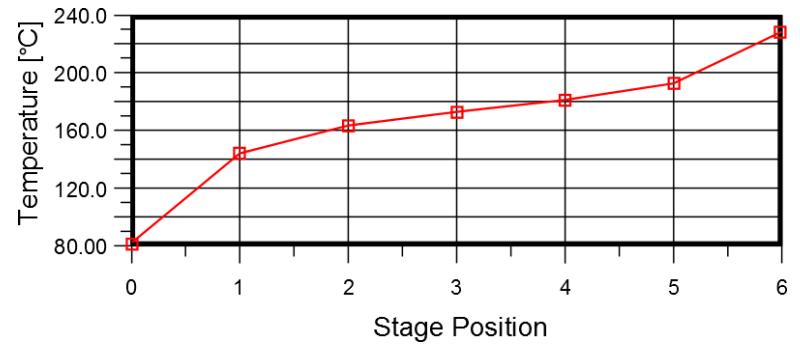

a)

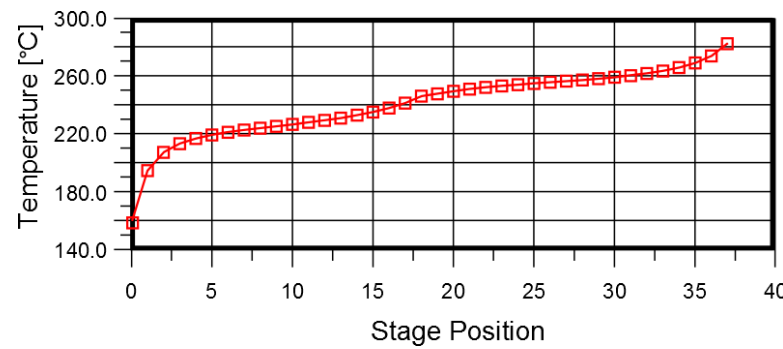

c)

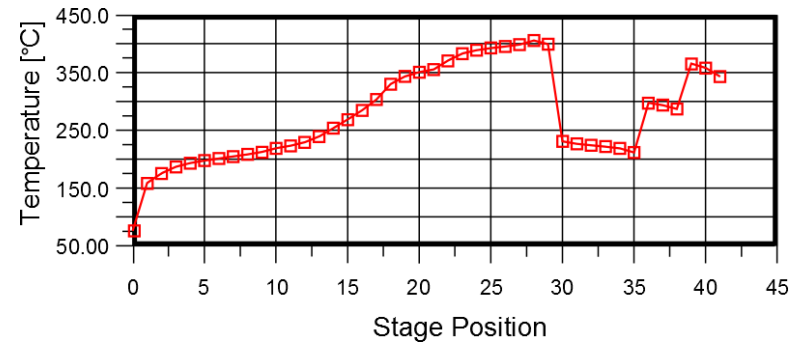

b)

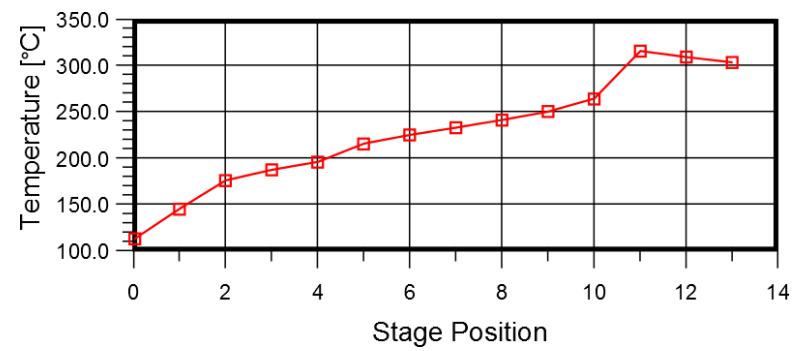

d)

Figure 10: Temperature profile of: a) preflash, b) atmospheric, c) stabilizer and d) vacuum columns.

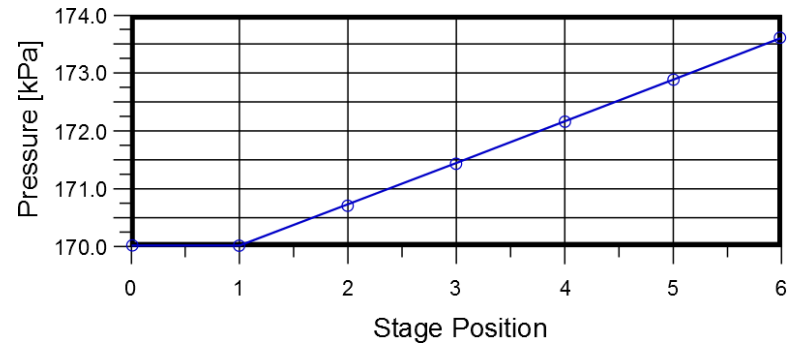

a)

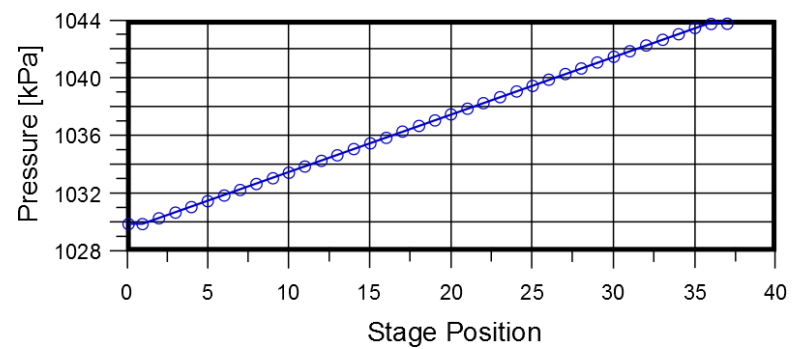

c)

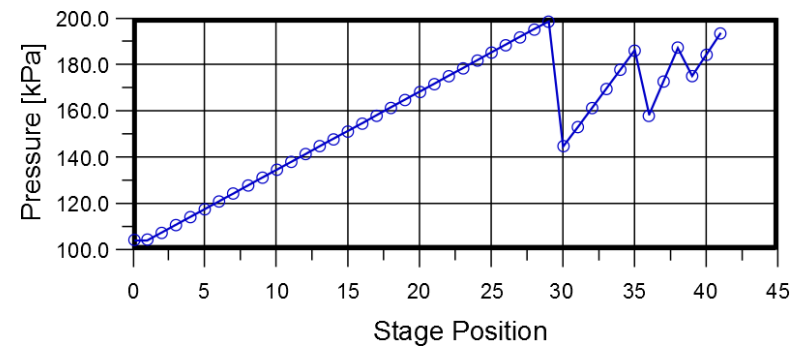

b)

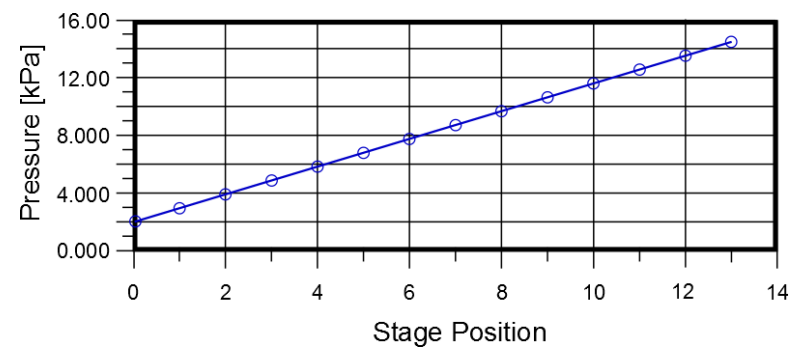

d)

Figure 11: Pressure profile of: a) preflash, b) atmospheric, c) stabilizer and d) vacuum columns.

\subsection{Dynamic mode results}

The simulated disturbances applied to the system correspond to typical composition changes of crude oil feed flowrate in a distillation plant of Mexico, Fig. 12. 
Sotelo, Favela-Contreras, Lozoya, Beltran-Carbajal, Dieck-Assad, Sotelo: Dynamic ...

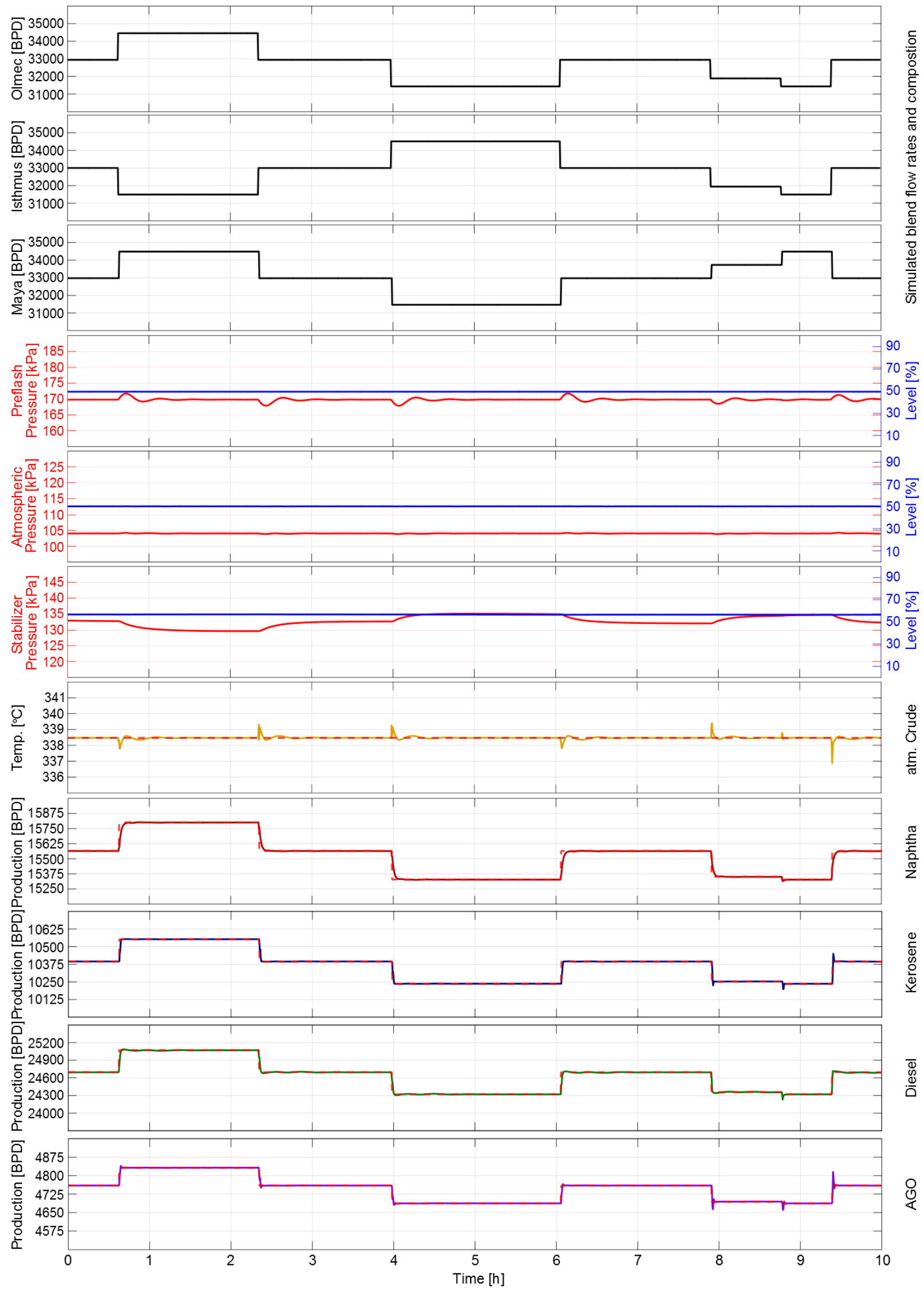

Figure 12: Simulation results in dynamic mode. 
As it is shown in Fig. 12, the top pressure of columns (red line) remains at their actual values (see Table VIII) and the liquid level in condensers (blue line) is maintained close to $50 \%$ of the total capacity. Additionally, the temperature of crude oil feed into the atmospheric distillation column is regulated at $338.4{ }^{\circ} \mathrm{C}$, with $336.7^{\circ} \mathrm{C}$ as minimum and $340^{\circ} \mathrm{C}$ as maximum. Moreover, the distillates yields of naphtha, kerosene, diesel, and AGO (solid lines) follow the specified references values (dashed lines), according to the fractions shown in Fig. 7 and the total crude oil feed into the distillation plant. Finally, a box and whisker plot (Fig. 13) is used to describe the degree of dispersion and skewness in the temperatures data of distillate products. As it can be seen, the variability outside the lower and upper quartiles of the operating temperatures is uniformly distributed, and the whiskers are into the ranges of temperatures specified in Table I.
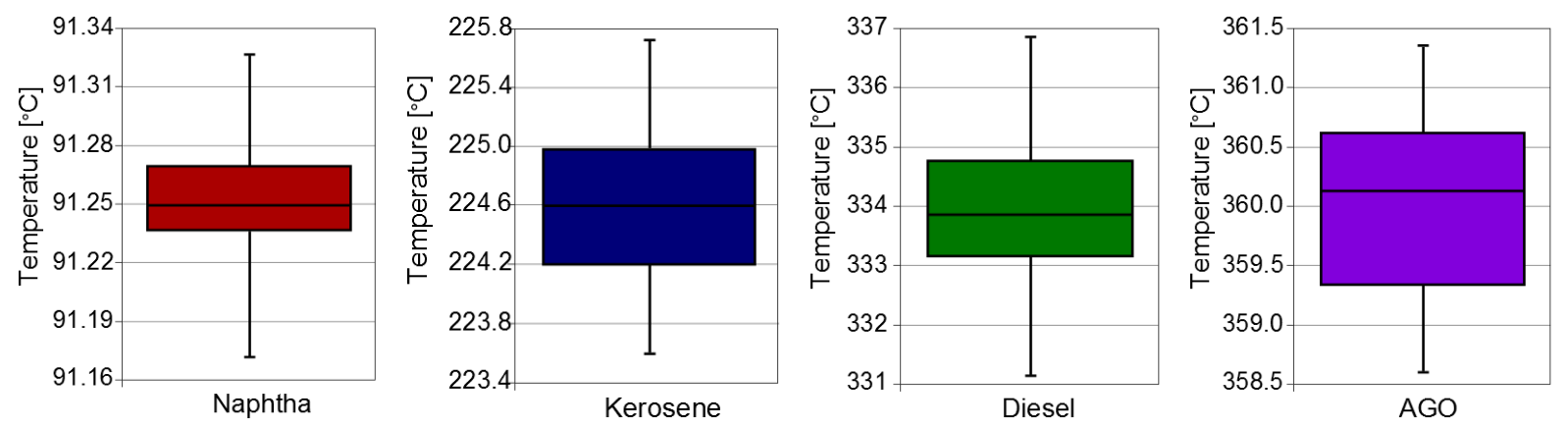

Figure 13: Temperatures variability of distillate products.

\section{CONCLUSION}

The present work concerns the application of Aspen HYSYS ${ }^{\circledR}$ environment to simulate an entire crude oil distillation plant in dynamic mode. Considering a mixture of three crude oils and based on a deep literature review, distillation units are carefully designed to generate a rigorous and accurate dynamic simulation. The steady state simulation results such as top pressure, weir length and column diameters are compared with theoretical values specified in the research field. Moreover, a suitable control structure is implemented to preserve operating conditions in dynamic regime when unexpected input flow changes occur. Then, this work enables a better understanding of the process behaviour during routing operation and serves as a scientific platform to develop advanced control strategies for future researches.

\section{ACKNOWLEDGEMENT}

Financial support from Tecnologico de Monterrey and the National Council for Science and Technology (CONACYT), México is gratefully acknowledged. Also, the authors would like to express their deepest gratitude to Sensors and Devices research group of the School of Engineering and Sciences for giving helpful comments and suggestions.

\section{REFERENCES}

[1] Gonçalves, D. D.; Martins, F. G.; de Azevedo, S. F. (2010). Dynamic simulation and control: application to atmospheric distillation unit of crude oil refinery, Proceedings of the $20^{\text {th }}$ European Symposium on Computer Aided Chemical Engineering, 36-52

[2] Marion, G.; Lawson, D. (2008). An Introduction to Mathematical Modelling, University of Bristol, Bristol

[3] Rãdulescu, G. (2007). An original approach for the dynamic simulation of a crude oil distillation plant, Revista de Chimie, Vol. 58, No. 3, 239-242 
[4] Abdullah, Z.; Aziz, N.; Ahmad, Z. (2007). Nonlinear modelling application in distillation column, Chemical Product and Process Modeling, Vol. 2, No. 3, doi:10.2202/1934-2659.1082

[5] Jibril, M.; Folorunsho, A. D.; Manasseh, A. (2012). Simulation of Kaduna refining and petrochemical company (KRPC) crude distillation unit (CDU I) using Hysys, International Journal of Advanced Scientific Research and Technology, Vol. 1, No. 2, 1-6

[6] Dave, D. J.; Dabhiya, M. Z.; Satyadev, S. V. K.; Ganguly, S.; Saraf, D. N. (2003). Online tuning of a steady state crude distillation unit model for real time applications, Journal of Process Control, Vol. 13, No. 3, 267-282, doi:10.1016/S0959-1524(02)00026-4

[7] Anitha, K.; Shuwana, T.; Kumar, V. R. (2011). Simulation of atmospheric and vacuum crude units using Aspen Plus, Petroleum Science and Technology, Vol. 29, No. 18, 1885-1894, doi: $10.1080 / 10916461003663057$

[8] Haydary, J.; Pavlik, T. (2009). Steady-state and dynamic simulation of crude oil distillation using Aspen Plus and Aspen Dynamics, Petroleum \& Coal, Vol. 51, No. 2, 100-109

[9] Rãdulescu, G.; Paraschiv, N.; Marinoiu, V. (2000). Dynamic simulation of a crude oil unit, Buletinul Universităţii Petrol-Gaze din Ploieşti, Seria Tehnică, Vol. 52, No. 1, 207-212

[10] Parthiban, N.; Nagarajan, N.; Mahendra, V. K.; Senthil, K. D. (2013). Dynamic modeling and simulation of crude fractionation column with three side strippers using Aspen HYSYS Dynamics: A best practice for crude distillation column dynamic modeling, Journal of Petroleum and Gas Exploration Research, Vol. 3, No. 3, 31-39

[11] Doust, A. M.; Shahraki, F.; Sadeghi, J. (2012). Simulation, control and sensitivity analysis of crude oil distillation unit, Journal of Petroleum and Gas Engineering, Vol. 3, No. 6, 99-113

[12] Stopakevych, A. A. (2015). Robust control system design of crude oil atmospheric distillation column, Eastern-European Journal of Enterprise Technologies, Vol. 5, No. 2, 49-57, doi:10.15587/1729-4061.2015.50964

[13] Kemaloğlu, S.; Kuzu, E. O.; Gökçe, D.; Cetin, O. (2009). Model predictive control of a crude distillation unit an industrial application, IFAC Proceedings Volumes, Vol. 42, No. 11, 880-885, doi:10.3182/20090712-4-TR-2008.00144

[14] Raimondi, A.; Favela-Contreras, A.; Beltrán-Carbajal, F.; Piñón-Rubio, A.; de la Peña-Elizondo, J. L. (2015). Design of an adaptive predictive control strategy for crude oil atmospheric distillation process, Control Engineering Practice, Vol. 34, 39-48, doi:10.1016/ j.conengprac.2014.09.014

[15] Yamashita, A. S.; Zanin, A. C.; Odloak, D. (2016). Tuning the model predictive control of a crude distillation unit, ISA Transactions, Vol. 60, 178-190, doi:10.1016/j.isatra.2015.10.017

[16] Menezes, B. C.; Kelly, J. D.; Grossmann, I. E. (2013). Improved swing-cut modeling for planning and scheduling of oil-refinery distillation units, Industrial \& Engineering Chemistry Research, Vol. 52, No. 51, 18324-18333, doi:10.1021/ie4025775

[17] Ibrahim, D.; Jobson, M.; Guillén-Gosálbez, G. (2017). Optimization-based design of crude oil distillation units using rigorous simulation models, Industrial \& Engineering Chemistry Research, Vol. 56, No. 23, 6728-6740, doi:10.1021/acs.iecr.7b01014

[18] Tič, V.; Lovrec, D. (2012). Design of modern hydraulic tank using fluid flow simulation, International Journal of Simulation Modelling, Vol. 11, No. 2, 77-88, doi:10.2507/ IJSIMM11(2)2.202

[19] Sotelo, C.; Favela-Contreras, A.; Sotelo, D.; Beltrán-Carbajal, F.; Cruz, E. (2018). Control structure design for crude oil quality improvement in a dehydration and desalting process, Arabian Journal for Science and Engineering, Vol 42, No. 11, 6579-6594, doi:10.1007/s13369$\underline{018-3360-6}$

[20] Ekwonu, M. C.; Perry, S.; Oyedoh, E. A. (2013). Modelling and simulation of gas engines using Aspen HYSYS, Journal of Engineering Science and Technology, Vol. 6, No. 3, 1-4, doi: $10.25103 /$ jestr.063.01

[21] Aspen, T. (2008). Aspen HYSYS Dynamic Modeling, $2^{\text {nd }}$ edition, Aspen Technology Inc., Burlington

[22] Sinnott, R. K.; Coulson, J. M.; Richardson, J. F. (2005). Chemical Engineering Design, $4^{\text {th }}$ edition, Elsevier Butterworth-Heinemann, Oxford

[23] De Almeida Viseu, M. N. (2014). Dynamic Modelling of Batch Distillation Columns, Universidade de Lisboa, Lisbon 
[24] Luyben, W. L. (2014). Design and control of stacked-column distillation systems, Industrial \& Engineering Chemistry Research, Vol. 53, No. 33, 13139-13145, doi:10.1021/ie501981f

[25] Sotelo, D.; Favela-Contreras, A.; Sotelo, C.; Jiménez, G.; Gallegos-Canales, L. (2017). Design and implementation of a control structure for quality products in a crude oil atmospheric distillation column, ISA Transactions, Vol. 71, No. 2, 573-584, doi:10.1016/j.isatra.2017.08.005

[26] Fu, G.; Sanchez, Y.; Mahalec, V. (2015). Hybrid model for optimization of crude oil distillation units, AIChE Journal, Vol. 62, No. 4, 1065-1078, doi:10.1002/aic.15086

[27] Lovrec, D.; Tic, V.; Tasner, T. (2017). Dynamic behaviour of different hydraulic drive concepts - comparison and limits, International Journal of Simulation Modelling, Vol. 16, No. 3, 448-457, doi:10.2507/IJSIMM16(3)7.389

[28] Vu, T. N. L.; Lee, M. (2010). Independent design of multi-loop PI/PID controllers for interacting multivariable processes, Journal of Process Control, Vol. 20, No. 8, 922-933, doi:10.1016/j.jprocont.2010.06.012

[29] Luyben, W. L. (2012). Design of a petroleum preflash column, Energy \& Fuels, Vol. 26, No. 2, 1268-1274, doi:10.1021/ef201763g

[30] Habibullah, A. (2017). Crude and Vacuum Unit Design Challenges, Technical Report, 24 pages, Specialized Consulting Services, Los Angeles

[31] Gadalla, M. A.; Abdelaziz, O. Y.; Kamel, D. A.; Ashour, F. H. (2015). A rigorous simulationbased procedure for retrofitting an existing Egyptian refinery distillation unit, Energy, Vol. 83, 756-765, doi:10.1016/j.energy.2015.02.085

[32] Huang, H. (2000). Simulation and Control of Complex Distillation Processes, PhD Thesis, Texas Tech University, Lubbock

[33] García Gallego, M. A. (2012). Hysys. Destilación Atmosférica de crudo Petrolifero, PhD Thesis, Universidad de Sevilla, Escuela Superior de Ingenieros, Sevilla

[34] Anderson, J. J. (1998). Vacuum Distillation Control, PhD Thesis, Texas Tech University, Lubbock

[35] Towler, G.; Sinnott, R. K. (2012). Chemical Engineering Design: Principles, Practice and Economics of Plant and Process Design, $6^{\text {th }}$ edition, Elsevier, Amsterdam 